\title{
CELEBRACIONES FÚNEBRES Y PROYECCIÓN SOCIO- RELIGIOSA DEL CABILDO DE CURAS Y BENEFICIADOS DE TOLEDO (1436-1488)
}

\author{
Jesús Olivet García-Dorado \\ Universidad de Castilla-La Mancha
}

\begin{abstract}
Resumen: El presente artículo tiene por objeto principal el estudio de los ritos funerarios solicitados por las élites toledanas al Cabido de Curas y Beneficiados, entre 1436 y 1488. En concreto, este trabajo se centra en el papel que jugaron las mandas fúnebres en la construcción de la memoria y escenificación del poder de las oligarquías urbanas, durante la Baja Edad Media. Mediante el estudio de siete obituarios, pretendemos mostrar cómo las honras fúnebres sirvieron como reflejo de su estatus social. A su vez, prestaremos una especial atención al impacto que tales encargos supusieron en la evolución económica e institucional del Cabildo de Curas y Beneficiados de Toledo.
\end{abstract}

Palabras clave: Cabildo de Curas y Beneficiados, siglo XV, Toledo, ritos funerarios, élites, corporaciones clericales.

FUNERAL RITES AND SOCIO-RELIGIOUS PROJECTION OF THE CHAPTER OF PRIESTS AND INCUMBENTS OF TOLEDO (1436-1488)

Abstract: The main of this paper is the study of funeral rites requested by the elites of Toledo to the Chapter of Priests and Incumbents between 1436 and 1488. It focuses specifically on how these rituals helped to build the memory and represent the power of urban oligarchies during the Late Middle Ages. Seven obituaries are studied in order to prove that funeral rites were a reflection of the social status of the elites. In addition, special attention is paid to the impact those requests had on the economic and institutional progress of the Chapter of Priests and Incumbents of Toledo.

Key words: Chapter of Priests and Incumbents, $15^{\text {th }}$ century, Toledo, funeral rites, élites, clerics' brotherhoods.

\footnotetext{
${ }^{*}$ Entregado: 15/05/2018. Aceptación definitiva: 19/11/2018
} 


\section{INTRODUCCIÓN}

Dos de las realidades socioculturales más representativas de la Baja Edad Media fueron la consolidación de entidades corporativas y la proliferación de las mandas funerarias ${ }^{1}$. Ambos fenómenos propiciaron el surgimiento de las hermandades de clérigos seculares, como el Cabildo de Curas y Beneficiados de Toledo ${ }^{2}$. Sus objetivos eran la ayuda mutua entre sus miembros y la celebración de las honras fúnebres, propias o de terceros.

El incremento de las mandas funerarias se debió a varios motivos. Sin duda, el factor religioso fue el más importante, dada la influencia del cristianismo en todos los aspectos sociales. Pero a su vez, los ritos funerarios tuvieron un importante componente profano: aquéllos plasmaban el deseo de las élites por manifestar la naturaleza inalterable de su estatus social más allá de la muerte. A cambio de estas celebraciones, las oligarquías donaron diversos recursos económicos al clero. Este proceso traería consigo considerables cambios en el desarrollo de las corporaciones eclesiásticas implicadas. Precisamente, aquí residen los dos ejes de este estudio: por un lado, el artículo abordará el papel de las exequias en la construcción social de la memoria de los poderosos; por otro, se analizará las consecuencias que dichos encargos supusieron en el patrimonio y composición del Cabildo de Curas y Beneficiados.

La historiografía medieval española ha tratado de forma desigual los temas de este trabajo. Sobre las mandas funerarias de las élites, la mayor parte de los estudios se han acercado a la cuestión desde una perspectiva general y en clave territorial: Susana Royer Cardinal y Fernando Martínez Gil para Castilla ${ }^{3}$, María del Carmen Herrero y María Luisa Falcón para Aragón ${ }^{4}$, Julia Baldo Alcoz y Julia Pavón para Navarra ${ }^{5}$, por citar algunos. Todos ellos se interesaron por las actitudes mentales del individuo ante la muerte, la diversidad de los rituales religiosos o su periodicidad, entre otras cuestiones.

\footnotetext{
${ }^{1}$ Como se irá viendo en el texto, el término alude a las celebraciones religiosas encargadas por un particular al cabildo, para que se oficien tras su muerte a fin de obtener la salvación eterna.

${ }^{2}$ El término cabildo posee varias acepciones. Una se refiere al conjunto de clérigos que servía en una colegiata o una catedral. El segundo significado alude a una corporación socio-profesional constituida para la defensa de sus intereses. Esta última denominación se utilizó para designar algunas cofradías de clérigos, como el propio Cabildo de Curas y Beneficiados de Toledo. Olivet GARCÍA-DorAdo, J., «El Cabildo de Curas y Beneficiados de Toledo. Composición y aspectos institucionales (1455-1488)», Espacio, tiempo y forma. Serie III. Historia Medieval, 31 (2018), p.522.

${ }^{3}$ Royer, S., Morir en España. Castilla. Baja Edad Media, Universidad Católica Argentina, Buenos Aires, 1989. MARTínez GIL, F., La muerte vivida. Muerte y sociedad en Castilla durante la Baja Edad Media, Diputación Provincial de Toledo, Toledo, 1996.

${ }^{4}$ García Herrero, M.C., y FAlcón PÉrez, M.I., «En torno a la muerte a finales de la Edad Media aragonesa», En la España Medieval, 29 (2006), pp.153-186.

5 BALDO AlCOZ, J., «La tradición cristiana del culto a los difuntos: sufragios, misas e indulgencias», De la tierra al cielo. Ubi sunt qui ante nos in hoc mundo fuere? XXIV Semana de Estudios Medievales, Nájera, del 29 de julio al 2 de agosto de 2013, LÓPEZ OJEDA, E. (ed.), Instituto de Estudios Riojanos, Logroño, 2014, pp.141-188. PAVÓn Benito, J., y GArcía de LA Borbolla, Á., Morir en la Edad Media. La muerte en la Navarra medieval, Universitat de València, Valencia, 2007.
} 
Algunos trabajos se han centrado específicamente en la cuestión. Cabe citar las investigaciones de Isabel Beceiro Pita ${ }^{6}$ sobre las capellanías nobiliarias. Para esta autora, el rasgo más relevante de estas fundaciones reside en su función simbólica: la concienciación del ilustre pasado familiar entre los miembros del linaje. Otras aportaciones interesantes son las de José Antonio Jara Fuente, que analizó las honras fúnebres de la alta nobleza como herramientas al servicio del orden establecido ${ }^{7}$, aduciendo varias razones. Entre las más destacadas, Jara enfatizó la naturaleza social de las celebraciones funerarias, ya que, en ellas, participaban individuos procedentes de todos los estamentos sociales. Asimismo, este investigador presentó a estas ceremonias como la escenificación de la alianza de los estamentos privilegiados. Si el clero se beneficiaba de las aportaciones de la nobleza, la aristocracia mostraba su posición social preeminente a través de los servicios religiosos. Por último, las generosas dádivas, repartidas entre los asistentes más necesitados, servían nuevamente para la preservación de la sociedad estamental. Por su parte, las observaciones de Miguel Ángel Recio y María Jesús Izquierdo constataron el peso de las mandas funerarias en el proceso de aristocratización del patriciado urbano ${ }^{8}$. En concreto, dichos autores plasmaron cómo las élites burguesas palentinas materializaron sus aspiraciones de ascenso social a través de diversas estrategias, tales como la adquisición de propiedades rústicas, el control de la vida política municipal y, por último, la erección de capellanías, equiparándose así a la nobleza.

Ya en el contexto toledano, Jean Pierre Molènat vinculó las instituciones del mayorazgo y la capellanía al afán de la aristocracia por consolidar la noción de linaje, mediante la conservación de su patrimonio y el recuerdo de sus antepasados ${ }^{9}$. También, Juan Ramón Palencia se interesó la relación existente entre las exequias y la memoria familiar, como reflejó en su estudio sobre los López de Ayala ${ }^{10}$. Otro trabajo relevante fue el ensayo sobre las cláusulas testamentarias de los canónigos toledanos ${ }^{11}$, compuesto por José Luis Soto. Su aspecto más destacado es la similitud existente entre las actitudes ante la muerte y las prácticas funerarias de los canónigos y las de la aristocracia laica. Además, el libro alude a la presencia del Cabildo de Curas y Beneficiados en las honras de algunos capitulares. Por último, se hace obligado mencionar el artículo de

\footnotetext{
${ }^{6}$ BeCEIRo PitA, I., «La conciencia de los antepasados y gloria del linaje en la Castilla bajomedieval», Relaciones de poder, de producción y parentesco en la Edad Media y Moderna. PASTOR DE TORNERI, R. (comp.), Centro Superior de Investigaciones Científicas, Madrid, 1990, pp.329-351.

${ }^{7}$ JARA FUENTE, J.A., «Muerte, ceremonial y ritual funerario: procesos de cohesión intraestamental y de control social en la alta aristocracia del Antiguo Régimen (Corona de Castilla, siglos XV-XVIII)», Hispania: Revista española de Historia, 194 (1996), pp.861-883.

${ }^{8}$ ESTEBAN RECIO, M.Á., e IZQUIERDO GARCÍA, M.J., «Familias burguesas representantes de la élite palentina a fines de la Edad Media», Studia histórica. Historia medieval, 10 (1992), pp.101-147.

${ }^{9}$ MolenAT, J.P., «La volonté de durer: majorats et chapellenies dans la pratique tolédane des XIII ${ }^{\mathrm{e}}-\mathrm{XV}^{\mathrm{e}}$ siècle», En la España Medieval, 5 (1986), pp.683-696.

${ }^{10}$ PALENCIA HeRrejón, J.R., «Elementos simbólicos de poder de la nobleza urbana en Castilla: los Ayala de Toledo al final del Medievo», En la España Medieval, 11 (1995), pp.163-180.

${ }^{11}$ Barrios Soto, J.L., Vida, Iglesia y Cultura en la Edad Media. Testamentos en torno al cabildo toledano del siglo XIV, Universidad de Alcalá, Alcalá de Henares, 2011.
} 
Ricardo Izquierdo Benito sobre el universo funerario toledano ${ }^{12}$, en el que se detalla el ordenamiento municipal de los entierros.

Las referencias bibliográficas sobre las corporaciones de clérigos seculares y parroquiales son más limitadas. Las claves del fenómeno y su implantación en Castilla fueron analizadas por José Luis Martín ${ }^{13}$, que comparó el corporativismo del clero secular con la irrupción de diversos colectivos socio profesionales, como los gremios. Asimismo, estudió varias hermandades clericales radicadas en el entorno rural castellano, mostrando un especial interés en las cuestiones relativas a su composición y a sus cometidos.

La mayoría de las investigaciones han abordado sólo algunas entidades locales ${ }^{14}$. Las monografías sobre su cometido funerario son aún pocas. Salvador Cortés, Rafael de Lucas, Carlos Sáez Sánchez y Jorge García Caparrós estudiaron el patrimonio que amansó el Cabildo de Clérigos de Guadalajara ${ }^{15}$ por su actividad funeraria. Otro ejemplo fue el estudio de Mauricio Herrero sobre el Cabildo de Clérigos de Cuéllar ${ }^{16}$, orientado a los servicios religiosos funerarios celebrados por los eclesiásticos. Más escasas han sido las obras referidas al Cabildo de Curas y Beneficiados de Toledo. Éstas han tratado diversas cuestiones como sus fondos documentales, con las catalogaciones realizadas por Antonio Sierra ${ }^{17}$ y por Mario Arellano ${ }^{18}$. No obstante, se aprecian grandes diferencias entre ambos autores. Si el trabajo de Sierra Corella obedece a una descripción genérica del archivo de la institución, Arellano clasifica los materiales desde sus orígenes al siglo XIX, atendiendo a su temática: documentos relativos a la labor religiosa (libros de entierros, obituarios), documentos de índole económica (préstamos, tributos, libros de posesiones) o los escritos referidos a los aspectos institucionales (libros de actas), por citar algunos.

\footnotetext{
${ }^{12}$ IZQUIERDO BENITO, R., «Normas sobre lutos y entierros en Toledo en los siglos bajomedievales», $O s$ reinos ibéricos na Idade Média. Livro de homenagem ao professor doutor Humberto Carlos Baquero Moreno, FONSECA, L. A., y AMARAL, L.C. (coords.), Livraria Civilizaçào Editora, Lisboa, 2003, vol.2, pp.1272-1282.

${ }^{13}$ MARTín, J.L., «Hermandades y ligas de clérigos en los reinos hispánicos», Cofradías, gremios, solidaridades en la Edad Media. XIX Semana de Estudios Medievales, SESMA MUÑOZ, J.Á., et al. (eds.), Gobierno Foral de Navarra, Pamplona, 1996, pp.127-148. MARTín, J.L., «El clero rural en la Corona de Castilla», La Iglesia en el mundo medieval y moderno, MARTÍNEZ SAMPEDRO, M.D., y SEGURA DEL RÍO, M.D. (coords.), Instituto de Estudios Almerienses, Almería, 2004, pp.52-82.

${ }^{14}$ Para conocer un estado general de la cuestión, véase OlIVET GARCÍA-DORADO, J., «El Cabildo de Curas y Beneficiados de Toledo...», pp.521-523.

${ }^{15}$ Cortés Campoamor, S., De Lucas Vegas, R., SaÉz SÁnchez, C., y García Caparrós, J., «Patrimonio y obituario del cabildo eclesiástico de Guadalajara (1450c.)», Wad-al-Hayara: Revista de estudios de Guadalajara, 11 (1984), pp.59-96.

${ }^{16}$ Herrero Jiménez, M., «El cuidado del alma y otros cuidados en las cartas de aniversario del Cabildo de Clérigos de Cuéllar en el siglo XIV», Espacio, tiempo y forma. Serie IV. Historia Moderna, 29 (2016), pp.377-399.

Sierra Corella, A., «El Cabildo de Párrocos de Toledo. Fuentes históricas de su archivo», Revista de Archivos, 19 (1928), pp.97-114.

${ }^{18}$ Arellano García, M., Catálogo del archivo del Cabildo de Curas y Beneficiados de Toledo, Caja de Ahorros de Toledo, Toledo, 1984.
} 
Los orígenes de la corporación fueron esbozados en la historia de la archidiócesis de Toledo escrita por Juan Francisco Rivera Recio ${ }^{19}$. El canónigo recalcó el protagonismo que tuvo el Cabildo de Curas y Beneficiados en los enfrentamientos entre el clero parroquial toledano y el arzobispo durante el siglo XII. Más recientemente, algunos trabajos han estudiado los aspectos de la vida comunitaria. Cabe citar la publicación de Francisco José Aranda Pérez ${ }^{20}$, que describe los mecanismos de regulación interna del cabildo en el siglo XVII. Para el período medieval, destaca el artículo de Jesús Olivet García-Dorado $^{21}$. Éste trata diversos aspectos institucionales durante el siglo XV, tales como los cargos capitulares, las ordenanzas o las sanciones. No obstante, no existe ningún estudio que haya abordado la dimensión funeraria del cabildo, ni su vinculación con la alta sociedad toledana. De hecho, un aspecto significativo de esta investigación es que responde a dicho vacío historiográfico. Además, el presente artículo cuenta con más puntos de interés. Uno de ellos reside en el enorme valor simbólico de las mandas. Otro es el protagonismo de Toledo en la Corona de Castilla. El último responde al impacto socioeconómico de las citadas mandas sobre el Cabildo de Curas y Beneficiados, en concreto cómo los encargos procedentes de las oligarquías contribuyeron a su elitización.

Para la realización de este trabajo se han empleado siete fuentes, procedentes de los fondos seriados de la corporación, custodiados en el Archivo Diocesano de Toledo. Tales fuentes corresponden a los libros de presencias de 1436, 1446-1447, 1450-1451, $1455,1464,1472$ y 1488. Los libros de presencias son obituarios anuales, donde el cabildo registraba las misas pro defunctis. Junto al encargo, la institución anotaba el número de celebrantes y su ración económica, práctica que explica la denominación libros de presencias. La selección de los materiales documentales responde a los objetivos propuestos en este artículo. Pese al carácter escueto - y a veces incompleto- de las informaciones, las fuentes permiten conocer las mandas funerarias de las élites, por medio de diversas informaciones: el nombre de los donantes, sus encargos o sus aportaciones. Asimismo, el desarrollo institucional de la corporación se concreta en la relación de ingresos y gastos, el progresivo incremento de las raciones y la evolución de la composición del cabildo. A partir de estos datos, se articula el presente estudio. El primer epígrafe presentará brevemente la institución. Aquí se abordarán las cuestiones referidas al marco crono-espacial en el que apareció el cabildo, así como sus cometidos y sus aspectos institucionales más importantes. El segundo apartado ahondará en el contexto sociocultural, en el que se inscribe su actividad funeraria. El tercer punto versará sobre la procedencia social de los donantes; mientras el cuarto describirá los diversos tipos de las mandas funerarias. El artículo se cerrará con un apartado dedicado al impacto que

\footnotetext{
${ }^{19}$ Rivera Recio, J.F., La Iglesia de Toledo en el siglo XII, Diputación Provincial de Toledo, Toledo, 1976 , vol.2.

${ }^{20}$ ARANDA PÉREZ, F.J., «El clero también se acabilda: el Cabildo de los Curas y Beneficiados de Toledo», Sociedad y élites eclesiásticas en la España Moderna, ARANDA PÉREZ, F.J. (coord.), Universidad de Castilla-La Mancha, Cuenca, 2000, pp.237-288.

${ }^{21}$ Olivet GARCíA-DORADO, J., «El Cabildo de Curas y Beneficiados de Toledo...», pp.522-546.
} 
las donaciones de los poderosos supusieron sobre el cabildo. Finalmente, las conclusiones enfatizarán los puntos de interés de este estudio.

\section{El CABILdo de Curas y Beneficiados de Toledo}

Durante el siglo XV, Toledo era una de las principales ciudades de la Corona de Castilla. La urbe contaba con una elevada población y una bonanza económica, gracias al dinamismo de su artesanía diversificada y de su sector mercantil ${ }^{22}$. Asimismo, su situación estratégica propició la presencia frecuente de la corte, hecho que la hizo muy atractiva para algunas casas de la alta nobleza. Sin embargo, su rasgo más notorio fue su papel como ciudad eclesial. Toledo era la sede de una de las archidiócesis más extensas y ricas de la Península Ibérica, una importancia reforzada por su primacía honorífica sobre las diócesis hispánicas ${ }^{23}$.

La influencia de la Iglesia en Toledo se manifestaba en todo el marco urbano. A fines de la Edad Media, la ciudad poseía más de veinte fundaciones conventuales y monásticas, varios eremitorios, iglesias y hospitales ${ }^{24}$. La ciudad se dividía en 26 collaciones: en las zonas comerciales se emplazaban Santa María Magdalena, San Pedro, Santas Justa y Rufina, San Ginés y Todos los Santos. La mayoría se ubicaba en los barrios residenciales, como las parroquias de San Miguel, San Salvador, Santo Tomé, San Cristóbal, San Andrés, Santa Eulalia, Santa Leocadia, San Lorenzo, San Soles, San Cebrián y Santiago. Por último, las cuatro restantes se localizaban en el extrarradio: San Sebastián, San Lucas, San Marcos y San Torcuato ${ }^{25}$. Un rasgo propio del mapa parroquial toledano era su dualidad litúrgica: 6 de los templos parroquiales aún conservaban el rito mozárabe, heredero de la tradición hispano-goda. Pero, la diferencia más acusada era el desigual reparto de los recursos económicos y pastorales. Las collaciones del centro y de algunas zonas residenciales estaban bien dotadas; por el contrario, los medios de las parroquias del extrarradio eran deficitarios ${ }^{26}$.

La actividad del Cabildo de Curas y Beneficiados trascurrió en medio de este ambiente eclesial. Sus orígenes se remontan al siglo XII, fecha en la que el corporativismo clerical recorrió Europa Occidental. La corporación respondió a los objetivos propios de las hermandades de clérigos parroquiales: la ayuda mutua entre sus miembros -

\footnotetext{
${ }^{22}$ Según las estimaciones de Julio Martín- Porres Cleto, Toledo tendría unos 30.000 habitantes a comienzos del siglo XVI. MARtín Porres Cleto, J., «La ciudad de Toledo a mediados del siglo XV», Anales toledanos, 28 (1998), p.33.

${ }^{23}$ Olivet GARCÍA-DORADO, J., «El Cabildo de Curas y...», p.525.

${ }^{24}$ LOP OTÍN, M.J., «Parroquias y práctica sacramental en la diócesis de Toledo a fines de la Edad Media», Mundos medievales: espacios, sociedades y poder: homenaje al profesor José Ángel García de Cortázar y Ruiz de Aguirre, Arízaga Bolumburu, B., et. al. (eds.), Universidad de Cantabria, Santander, 2012, vol. 2, pp.1528-1529.

${ }^{25}$ BARrios Soto, J.L., Santo Domingo el Real y Toledo a fines de la Edad Media (1364-1507), Diputación Provincial de Toledo, Toledo, 1997, p.319.

${ }^{26}$ Para profundizar más al respecto, véase Lop OTín, M.J., «Iglesia y vida urbana. Las ciudades del arzobispado de Toledo a fines del Medievo», Edad Media. Revista de Historia, 15 (2014), pp.135-154.
} 
concretada en el reparto de las ganancias de la institución-, la defensa de sus intereses frente a la curia arzobispal y el culto funerario. Éste último era el más importante. Como entidad religiosa, su labor era celebrar aquellos sufragios necesarios para la salvación de los miembros difuntos. Asimismo, los capitulares oficiaban las mandas funerarias de los particulares que lo solicitasen ${ }^{27}$. Precisamente, el patrimonio capitular procedía de las donaciones que aquéllos hacían a la institución, realizadas en concepto de limosna. Las donaciones podían realizarse mediante la aportación de una cuantía monetaria o través de la cesión de casas o de explotaciones agrarias. Los ingresos procedentes de los donativos se empleaban para financiar las diversas partidas de la corporación, entre ellas el pago a los celebrantes:

«Lunes veinte e seis de disiembre del año del nascimiento de nuestro señor de Mil e quatroçientos e treinta e seis: el aniversario de Gonçalo Fernandes escudero y de su mujer, María Gonçales, el qual dexó una viña de sesenta mrs [...] Fueron raçionados treze, partense cincuenta maravedies, viene la raçión a quatro maravedies» ${ }^{28}$.

El grueso de la corporación lo constituían párrocos y beneficiados servideros, aunque es difícil discernir las atribuciones cultuales de los últimos, dada la parquedad de las fuentes. Otros colectivos menormente representados eran los capellanes y los miembros de los cabildos ${ }^{29}$ colegiales y catedralicios: Pedro Ildefonso $(\dagger 1451)$, abad de San Vicente; Rodrigo Alfonso (†1488), chantre de Santa Leocadia; Juan de Morales $(† 1478)$, deán de Sevilla y Alfonso García, canónigo de la catedral de Toledo (†1488). La composición se completaba con algunos laicos denominados hermanos legos, cuyo número se fue reduciendo progresivamente.

La vida comunitaria del cabildo se regía por tres elementos: la regla, los oficios y la asamblea capitular. La regla regulaba el sistema de elección de los oficios ${ }^{30}$, los criterios de ingreso y las sanciones contra los infractores de la normativa capitular. Los oficios designaban a los cargos de responsabilidad. Éstos eran cuatro: dos regidores, el mayordomo y el receptor. Los regidores eran un cargo colegiado, cuyas principales obligaciones eran garantizar el cumplimiento de la regla y mediar en las disputas internas. El mayordomo se responsabilizaba de la provisión del culto y de las finanzas ${ }^{31} \mathrm{y}$ el receptor recaudaba el pago de las honras fúnebres. Todos estos cargos eran electos anualmente y sus beneficiados percibían una gratificación adicional por sus servicios. Aunque los oficios se encargaran de las labores más importantes de la corporación, la

\footnotetext{
${ }^{27}$ Arellano García, M., Catálogo del archivo del Cabildo..., p. 14.

28 1436, diciembre, 26, Archivo Diocesano de Toledo [ADT], Cabildo de Párrocos, Libro de presencias de 1436 , ff. 89 r-90r.

${ }^{29}$ Conviene recordar el carácter polisémico del término cabildo. En este caso, se refiere a la institución que agrupaba a los clérigos que atendía litúrgicamente una catedral (o una colegiata). Sus integrantes rezaban colectivamente las horas canónicas y que eran beneficiarios de las rentas de la mesa capitular, el patrimonio de la catedral o colegiata a la que pertenecían.

${ }^{30} \mathrm{La}$ regla primitiva estuvo en vigor hasta 1569 . Aunque no se ha conservado, los libros de presencias y las actas capitulares del siglo XVI permiten reconstruir los aspectos arriba mencionados.

${ }^{31}$ Una de sus obligaciones era la redacción de la defensa anual, donde anotaba el régimen de ingresos y gastos. La primera defensa incorporada en las fuentes corresponde a la realizada en 1450 .
} 
asamblea capitular detentaba la máxima autoridad del cabildo. La asamblea estaba compuesta por el conjunto de clérigos y se reunía cada primer sábado de diciembre, para la elección de cargos; o bien, cuando la situación lo requiera. Durante el transcurso de sus sesiones, los participantes tomaban las decisiones que afectaban a la institución: la gestión de su patrimonio, la admisión de nuevos miembros o la penalización de quienes incumplieran algún aspecto de la regla, incluyendo a los regidores y mayordomos.

La evolución institucional puede dividirse en dos fases. La primera abarcó los siglos XII al XIII. Este período se caracterizó por las tensas relaciones entre el arzobispado y el cabildo, a consecuencia de los gravámenes impuestos sobre las parroquias toledanas. Aquí predominó su faceta corporativa. La segunda etapa se extendió durante las dos centurias siguientes. Su perfil eclesial se reforzó con la mejora de las relaciones con el prelado. Pero, sobre todo, ese giro se materializó en una mayor proyección socio-religiosa, a través de los encargos funerarios. El aumento de los sufragios será una constante a lo largo del siglo XV, como se verá en los próximos apartados.

\section{CONTEXTO SOCIOCULTURAL DE LAS MANDAS FUNERARIAS}

La actividad funeraria del cabildo se explica por la popularización de los sufragios pro-ánima, durante la Baja Edad Media. En su conjunto, la sociedad promovió estas ceremonias a través de las últimas voluntades. El testamento se convirtió en una suerte de pasaporte al Más Allá, donde el individuo solicitaba la celebración de diversos oficios religiosos a uno o más colectivos eclesiales. A cambio de los mismos, el testador distribuía parte de su patrimonio al clero oficiante. De igual modo, el otorgante podía financiar diversas obras de caridad. Los motivos que explican este fenómeno son dos: la concepción religiosa de la vida y el protagonismo del individuo en su medio social.

La primera razón responde a la visión cristiana de la existencia. La vida se entendía como un peregrinaje hacia el Más Allá. Por su parte, el otro mundo se concebía en un esquema tripartito dividido en el Cielo, para los salvados, el Infierno para los condenados y el Purgatorio. La consolidación de la creencia en el Purgatorio se dio hacia finales del siglo XI, en un contexto donde la responsabilidad individual y la primacía del espíritu sobre el cuerpo reforzaban la idea del juicio particular inmediato a la muerte. Así, el alma del fallecido comparecía ante Dios, para entrar en el estado ultraterreno que mereciera por su compromiso religioso. No obstante, la popularización del tercer lugar se debió realmente a otros factores. El Purgatorio rebajaba las duras exigencias para salvarse ${ }^{32}$, debido a que, tras un período de penitencia temporal, el fiel podría gozar de la visión beatífica de Dios. Esa espera podría reducirse considerablemente por medio de dos vías. La primera era la celebración de numerosas misas y rezos, con los que los fieles suplicaban la salvación del fallecido. La segunda era la acumulación de buenas obras. La caridad se podría practicar incluso después de la muerte, gracias a los donati-

${ }^{32}$ MARtínez GiL, F., La muerte vivida. Muerte y..., p.57. 
vos destinados a los más necesitados y/o a varias instituciones benéficas. El resultado fue la proliferación de las mandas funerarias, contribuyendo decisivamente al monopolio eclesiástico sobre el discurso de la muerte y un considerable aumento del patrimonio e ingresos de los institutos religiosos, que las realizaron.

La segunda razón fue la emergencia del individuo, como protagonista de las relaciones sociales $^{33}$. Esta corriente de pensamiento se consolidó entre los siglos XIV y XV. La religiosidad reflejó este proceso enfatizando la responsabilidad de cada persona en su salvación. Pero, los estamentos privilegiados y acomodados acudieron a las mandas pías para sus propios fines, puesto que buscaban contrarrestar el carácter igualitario de la muerte por medio de tres estrategias: el boato ceremonial, las ceremonias religiosas y las limosnas.

Las fuentes se hacen eco de la predilección por parte de la aristocracia y el alto clero $^{34}$ hacia las celebraciones litúrgicas suntuosas, provistas de un lenguaje sensorial concretado en la combinación de varios elementos paralitúrgicos. Algunos eran el tañido de las campanas, el uso del incienso, la presencia de un elevado número de cetros y el uso de vestimentas litúrgicas, ricamente elaboradas en materiales nobles. La intención era consolidar la fama pública del finado, acreditando su estatus social ante su comuni$\mathrm{dad}^{35}$. La desmedida atención de los poderosos hacia los elementos paralitúrgicos conllevó la aprobación de ordenanzas municipales, para frenar los excesos. Por ejemplo, el consistorio toledano limitó el número de cirios utilizados durante el sepelio, en $1493^{36}$; aunque se desconoce la efectividad real de tales medidas.

El encargo del mayor número de misas y rezos posibles se debía al considerable patrimonio de los clérigos y los nobles, quienes podían sufragar estos encargos y promover su repetición cíclica, décadas después de su fallecimiento. Aparte de la motivación religiosa, las celebraciones solicitadas por la nobleza representaban simbólicamente la continuidad del linaje, haciendo memoria de los antepasados ${ }^{37}$. Otra connotación propia de la repetición de las conmemoraciones era su clara vocación sociopolítica. El constante recuerdo de aquellos aristócratas o jerarcas eclesiásticos corroboraba la vigencia de las relaciones sociales ${ }^{38}$. Este factor conectaba con la tercera de las estrategias, las limosnas, práctica donde las convicciones religiosas convergían con otras cuestiones más mundanas. La búsqueda de la salvación no era incompatible

\footnotetext{
${ }^{33}$ Duby, G., «La emergencia del individuo», Historia de la vida privada. De la Europa feudal al Renacimiento, ARIÉS, P., y DUBY, G. (dirs.), Taurus, Altea, 1991, vol.2, p.551.

${ }^{34}$ GuiJARro GonZÁLEZ, S., El buen façer, el buen morir y la remembranza en la sociedad medieval burgalesa (siglos XIII-XV), Universidad de Cantabria, Santander, 2016, pp.40-41.

${ }^{35}$ SolÓRZANO TElECHEA, J., «La dimensión sociopolítica de la enfermedad y la muerte en las villas portuarias de Cantabria en la Baja Edad Media», La muerte en el nordeste de la Corona de Castilla a finales de la Edad Media. Estudios y documentos, GONZÁLEZ MíNGUEZ, C., y BAZÁN DíAZ, I. (eds.), Universidad del País Vasco, Bilbao, 2014, p.67.

${ }^{36}$ IZQUIERDO BENITO, R., «Normas sobre los lutos y entierros...», p.1278.

${ }^{37}$ SÁNCHEZ SESA, R., «Modelos de muerte y mentalidad religiosa en la Península Ibérica. Los testamentos entre las élites castellanas de la segunda mitad del siglo XIV a la segunda del XIV», Ilu. Revista de Ciencias de las Religiones, 5 (2000), p.171.

${ }^{38}$ JARA FUENTE, J.A., «Muerte, ceremonial y ritual funerario...», pp.865-866.
} 
con el afán por generar un buen recuerdo en el imaginario social. El reparto de dádivas bien dotadas entre los últimos de la sociedad aseguraba el prestigio personal de los otorgantes y por extensión, la aceptación del orden estamental.

Las élites del estamento llano imitaron tales estrategias con el objeto de equipararse a la aristocracia. Como ya se mencionará líneas atrás, el lenguaje sensorial de los ritos funerarios, la continua celebración de las conmemoraciones y las limosnas evidenciaban públicamente una posición social privilegiada. Si los pecheros acomodados pretendían ingresar en el cuerpo social de la nobleza, las mandas funerarias era un elemento indispensable para la consecución de tal objetivo ${ }^{39}$.

\section{LOS DONANTES DEL CABILDO}

Entre 1436 y 1488, los libros de presencias recogen los encargos de más de 186 individuos. El grueso de los otorgantes pertenecía al bajo clero y al estamento llano, mientras los individuos procedentes de los sectores mejor situados representaban el $33,33 \%$ del total:

Procedencia social de los otorgantes potentados ${ }^{40}$

\begin{tabular}{|c|c|c|c|c|c|c|c|}
\hline Estamento & Prelados & Canónigos & $\begin{array}{c}\text { Alta Aristo- } \\
\text { cracia }\end{array}$ & $\begin{array}{c}\text { Caballeros } \\
\text { e hidalgos }\end{array}$ & $\begin{array}{c}\text { II.MM } \\
\text { (1) }\end{array}$ & $\begin{array}{c}\text { Profesionales } \\
\text { liberales }\end{array}$ & Mercaderes \\
\hline Porcentaje & $11,29 \%$ & $37,09 \%$ & $6,45 \%$ & $20,96 \%$ & $8,06 \%$ & $11,29 \%$ & $4,83 \%$ \\
\hline $\begin{array}{c}\text { N. de indi- } \\
\text { viduos }\end{array}$ & 7 & 23 & 4 & 13 & 5 & 7 & 3 \\
\hline Total & & & 62 & & & \\
\hline
\end{tabular}

Muchos de éstos fueron protagonistas de la vida sociopolítica castellana. Entre los jerarcas eclesiásticos, se hallan los prelados Gil Carrillo de Albornoz (1338-1350) ${ }^{42}$, uno de los más estrechos colaboradores de Clemente VI; Gómez Manrique (13621375), personaje muy influyente bajo el reinado de Enrique II; Juan de Cerezuela (14341442), hermano de Álvaro de Luna y Guiterre Álvarez de Toledo (1442-1445), uno de los protagonistas del convulso reinado de Juan II $^{43}$. Todos ellos procedían de las familias más poderosas del reino. Esta situación era una tendencia habitual entre los

\footnotetext{
${ }^{39}$ Esteban Recio, M.Á., e IzQUIERdo GArcía, M.J., «Familias burguesas representantes de la élite...», p. 128.

${ }^{40}$ Todas las tablas han sido elaboradas por el autor del artículo, a partir de los datos obtenidos en la investigación.

${ }^{41}$ Miembros de las instituciones municipales.

${ }^{42}$ Las fechas entre paréntesis se refieren a su pontificado toledano.

${ }^{43}$ Rivera Recio, J.F., Los arzobispos de Toledo en la Baja Edad Media (s. XII-XV), Diputación Provincial de Toledo, Toledo, 1969, pp.117-118.
} 
segundones de la aristocracia, ya que las mitras reportaban un considerable patrimonio. Además, los arzobispos gozaban de un marcado prestigio, fruto de la propia dignidad eclesial, como de las tareas políticas que llevaban consigo ${ }^{44}$.

Otros bienhechores pertenecían al poderoso cabildo catedralicio, órgano colegiado encargado del culto en el templo diocesano. La corporación constituía un auténtico grupo de poder en el Toledo bajomedieval, puesto que sus integrantes contaban con recursos económicos considerables, procedentes de su actividad cultual, del desempeño de algunas labores institucionales y de su fortuna personal ${ }^{45}$. El cabildo catedralicio presentaba una rígida jerarquía encabezada por las dignidades y cerrada por los racioneros. Las dignidades eran los cargos más importantes de la corporación, tales como el deán, presidente del cabildo catedral; el capellán mayor, encargado de las conmemoraciones funerarias en el templo diocesano ${ }^{46}$; el chantre, responsable de la gestión económica y la coordinación del canto y de la liturgia ${ }^{47}$; el maestreescuela, supervisor de la formación de los clérigos; los abades de San Vicente y de Santa Leocadia, máximas autoridades de dichas colegiatas ${ }^{48}$ y por último, los arcedianos, cuyas atribuciones eran el control del clero, la recaudación de impuestos y la administración del patrimonio en las diversas demarcaciones del arzobispado ${ }^{49}$. Las fuentes citan varios individuos, procedentes de las dignidades: el capellán mayor Diego de Villaescusa (†1488), los chantres Alfonso de Guerça (†1472) y Gonzalo Sánchez de Sevilla (†1472); el abad de San Vicente, Pedro Ildefonso $(† 1450)$ y los arcedianos Martín Fernández (†1446), Tello de Buendía (†1488), Luis Gómez (†1472), Luis Torres (†1488) y Gonzalo de Prado $(\dagger 1488)$.

Los canónigos constituían el siguiente escalafón del cabildo catedralicio. Se dividían en dos tipos: los mansionados y los extravagantes. Los primeros se distinguían por su esmerada formación cultural y por su gran fortuna, acrecentada con su acceso a las mejores prebendas ${ }^{50}$. Muchos de los mansionados procedían de las casas nobles de Toledo ${ }^{51}$ como Fernán Pérez de Ayala $(† 1472)$ y Diego Gutiérrez de Villacan $(\dagger 1472)$,

\footnotetext{
${ }^{44}$ DíAZ IBÁÑEZ, J., «La incorporación al alto clero en el reino de Castilla durante la Baja Edad Media», Anuario de Estudios Medievales, vol. 35, 2 (2005), p.558.

${ }^{45}$ Lop OTín, M.J., «Un grupo de poder a fines de la Edad Media: los canónigos de la catedral de Toledo», Anuario de Estudios Medievales, vol. 35, 2 (2005), p.642.

${ }^{46}$ Lop OTín, M.J., La catedral de Toledo en la Edad Media, Instituto Teológico de San Ildefonso, Toledo, 2008, p.61.

${ }^{47}$ LOP OTÍN, M.J., La catedral de Toledo..., p.55.

${ }^{48}$ Templo que contaba con un cabildo de canónigos sin ejercer como sede catedralicia. La presencia de un colegio canónico en su seno se debía a varias razones: la propia tradición del templo, el interés por darle una mayor relevancia o el deseo de un grupo de clérigos seculares por llevar una vida en común, si bien en la Baja Edad Media, tal deseo se redujo al rezo comunitario de horas. Las colegiatas de Santa Leocadia y San Vicente se ubicaban cerca de la ciudad: Santa Leocadia en los extramuros de Toledo y San Vicente en la localidad cercana de Hinojosa. La presencia de los abades de Santa Leocadia y San Vicente en el cabildo catedral se remonta al siglo XIV. LOP OTín, M.J., La catedral de Toledo ..., p.59.

${ }^{49}$ No obstante, los arcedianos habían perdido muchas de estas atribuciones hacia el siglo XV. LOP OTín, M.J., La catedral de Toledo..., p.58.

${ }^{50}$ LOP OTín, M.J., «Iglesia y vida urbana. Las ciudades...», p.140.

${ }^{51}$ LOP OTÍN, M.J., «Un grupo de poder a fines...», p. 638.
} 
miembros de los linajes Ayala y Silva respectivamente, Por el contrario, las rentas e influencia social de los canónigos extravagantes eran mucho más reducidas. No obstante, salvo las excepciones anteriores, las fuentes no distinguen entre una y otra categoría de canónigos. Aparte del alto clero toledano, los libros de presencias mencionan algunos integrantes de otros cabildos catedralicios, como el citado Juan de Morales (†1478), deán de Sevilla y arcediano de Sigüenza. Este clérigo fue uno de los mayores benefactores del Cabildo de Curas, puesto que había sido integrante del mismo.

La alta aristocracia está representada por Guiomar Suárez de Meneses, hija del alcalde de las alzadas de Toledo $(\dagger 1454)$; Gutierre de Toledo, aposentador del rey $(\dagger$ 1464); Juan de Silva Meneses (†1464), hijo de la anterior y I conde de Cifuentes y Pedro López de Ayala, II conde de Fuensalida ( $\uparrow 1483)$, alcalde de las fortalezas de Toledo $^{52}$. Precisamente, los Silva y los López de Ayala se disputaron el control de la ciudad durante la segunda mitad del siglo $X^{53}$. Por su parte, la baja nobleza plantea mayores incógnitas. Los caballeros e hidalgos suman 13 individuos, cuyo tratamientodon, señor, honrado - permite identificarlos como tal. Pero más allá de sus nombres, no se detallan sus ocupaciones; excepto en el caso de los regidores Juan Gudiel ( $\uparrow 1436)$ y Guillermo Vázquez ( $† 1488)$, puesto que el oficio de regidor era un cargo vitalicio reservado a la nobleza local, al que se accedía por designación real ${ }^{54}$. Posiblemente, el resto se integró en el consistorio, pues los linajes locales habían monopolizado el control del ayuntamiento desde mediados del siglo XV.

Los otorgantes acomodados procedían de las instituciones municipales, de la burguesía comercial, del campo de la medicina o del ámbito de las leyes ${ }^{55}$. Algunos donantes ejercían oficios públicos como el alguacil Toribio de Ávila (†1458) y Alfonso Ruiz, integrante del Cabildo de Jurados, entidad encargada del control de los precios y de los padrones fiscales y militares ${ }^{56}$. El sector mercantil queda representado por Juan González $(† 1450)$, el cambista Juan de Torrejón (†1488) y el esposo de Jacoba Palo $(† 1488)$. Posiblemente, también éste último tuviera parte en el negocio de la seda dada su procedencia, puesto que Toledo contaba con una colonia genovesa, dedicada a este sector $^{57}$. Por último, los profesionales liberales constituyen el colectivo más numeroso, presente en las fuentes con el maestre cirujano Pedro $(† 1488)$ y los escribanos Fernán Pérez (†1464), Pedro Sánchez de Guadalupe (†1464), Alfonso Fernández de Oseguera

\footnotetext{
52 SÁNChEZ BENITO, J.M., «Nobleza territorial y política ciudadana en el siglo XV (los concejos del área del Tajo)», Espacio, tiempo y forma. Serie III. Historia Medieval, 27 (2014), p.465.

${ }^{53}$ Benito RuAno, E., Toledo en el siglo XV, Consejo Superior de Investigaciones Científicas, Madrid, 1962, p.113.

${ }^{54}$ CANABAL RodríGUEZ, L., «Grupos y niveles de poder en Toledo», Espacios de poder: cortes, ciudades y villas (ss. XVI-XVIII), BRAVO, J. (ed.), Universidad Autónoma de Madrid, Madrid, 2002, vol.2, p.435.

${ }_{55}$ LÓPEZ GÓMEZ, Ó., «Élites urbanas y conflictividad social. Una reflexión a partir del caso de Toledo en el siglo XV», Vínculos de Historia, 4 (2015), p. 243.

${ }^{56}$ Esta institución servía como contrapeso al poder de la nobleza, ya que mientras ésta controlaba el ayuntamiento, la élite del común hacía lo propio con el Cabildo de Jurados. ArAnda PÉrez, F.J., Poder municipal y Cabildo de Jurados en Toledo en la Edad Moderna, Gráficas Toledo, Toledo, 1991, p.18.

${ }^{57}$ IguAl Luis, D., y NAVARRo EspinACH, G., «Los genoveses en España en el tránsito del siglo XV al XVI», Historia. Instituciones. Documentos, 24 (1997), p.270.
} 
el Viejo $(† 1488)$ y Francisco Fernández de Oseguera (†1488). Éstos últimos contarían con unos ingresos estables y una buena reputación social, ya que la cultura de lo escrito se fue imponiendo en los más variados asuntos cotidianos ${ }^{58}$. Como se observa, el perfil social del donante es heterogéneo. Una diversidad que a su vez se aprecia en la tipología de las mandas funerarias, como se describirán a continuación.

\section{LAS MANDAS FUNERARIAS DE LOS OTORGANTES}

Tanto los estamentos privilegiados como la burguesía emplearon importantes recursos económicos en la dotación de sus mandas. Este hecho explica cómo el 40,16\% de las más de las 605 honras, celebradas entre 1436 y 1488, fueran solicitadas por las oligarquías toledanas. Las diversas ceremonias se clasifican en dos tipos. Las primeras eran las celebraciones posmortem. Incluían desde el entierro a la misa de novenario. En cambio, las conmemoraciones obedecían a una periodicidad más prolongada: desde el año del fallecimiento hasta varias décadas, incluso siglos después.

Las celebraciones posmortem comenzaban tras el óbito. Tras la preparación del cadáver, los familiares y amigos del fallecido velaban su cadáver, al tiempo que recitaban los primeros rezos por el difunto. Al día siguiente, tenía lugar el sepelio. Éste se dividía en tres partes: el cortejo ceremonial, la propia inhumación y la misa de réquiem. La procesión funeraria es citada como acompañamiento o acompañamiento del ataúd. $\mathrm{Su}$ recorrido comenzaba desde la casa del finado hasta el templo, donde los restos mortales del fallecido serían enterrados. El cortejo fúnebre estaba presidido por la cruz, símbolo de la victoria de Cristo sobre el pecado y la muerte. Detrás de la cruz, se situaban los clérigos convocados, siendo frecuente la presencia de varios institutos religiosos — si el testador podía permitírselo- distribuidos en un estricto orden jerárquico. La presencia de los eclesiásticos reforzaba la imagen simbólica de aquel traslado como el tránsito hacia la verdadera vida ${ }^{59}$; pero a su vez, su participación expresaba la influencia social del individuo: cuantos más clérigos asistían al acompañamiento, mejor quedaba acreditada la piedad del difunto, su fortuna y su prestigio. Un ejemplo es el entierro de Vasco Ramírez de Rivera, obispo de Coria, que dispuso ser enterrado en el convento de Santo Domingo el Real (1488):

«Viernes a seys días de diciembre, este día a la tarde a las ocho de la noche fue el Cabildo de los Curas e Beneficiados a reçebir el cuerpo del honrado señor don Vasco obispo a la puente de Alcántara, porque le acompañaron fasta Santo Domingo el Real» ${ }^{60}$.

Otros participantes en la comitiva procedían de los colectivos más necesitados de la sociedad: viudas, mendigos, huérfanos o cautivos cristianos, rescatados en el norte de

\footnotetext{
${ }^{58}$ ExtremerA, M.Á., «Los escribanos de Castilla en la Edad Moderna. Nuevas líneas de investigación», Chronica Nova, 28 (2001), p.159.

${ }^{59}$ ROYER, S., Morir en España. Castilla. ..., p.165.

${ }^{60}$ 1488, diciembre, 6, ADT, Cabildo de Párrocos, Libro de presencias de 1488, f.127 r.
} 
África gracias a los donativos del testador. Su participación consolidaba la imagen del fallecido como benefactor de los más débiles ${ }^{61}$, ya que éste repartía algunas monedas, alimentos o vestidos ${ }^{62}$ entre los más menesterosos. Así lo hizo el chantre Alfonso de Guerça, con los cautivos rescatados, que lo acompañaron desde su domicilio al convento del Carmen $(1472)^{63}$. Más adelante, cuando el cortejo entraba en la iglesia, se procedía a dar cristiana sepultura al difunto. Los oficiantes administraban la aspersión de la sal y el agua bendita sobre la tumba para ahuyentar a los demonios ${ }^{64}$, mientras pronunciaban diversas oraciones. Algunos de estos rezos se describen en las mandas, por ejemplo, Ruiz Fernández, capellán de los Reyes Nuevos, solicitó el canto del invitatorio $^{65}$ y la letanía, oración que imploraba la intercesión de los santos:

«Veynte e nueve del mes de mayo fallesçió Rui Fernandes, clérigo capellán de los Reyes mandó al cabildo que le fisiesen sus honras. E mandolos doszientos mrs [...] Son racionados dies e siete para la vigilia e invitatorio e letanía ${ }^{66}$.

El sepelio concluía con una misa de réquiem, una práctica habitual en el ámbito castellano $^{67}$. Las mandas del primer ciclo se extendían hasta los nueve días. Durante este período, algunos otorgantes solicitaban otras dos misas de réquiem para simbolizar el tercer día, en que el Salvador había resucitado entre los muertos. La misa era el más eficaz de los sufragios, porque en ella se re-presentaba el sacrificio de Cristo durante la consagración del pan y del vino ${ }^{68}$. Por esta razón, la repetición del misterio de la redención aceleraba el ingreso del fallecido en el Paraíso; sin embargo, la solicitud de misas también pudo deberse a otras cuestiones, como facilitar la participación de sus deudos. Con todo, los encargos de las misas posmortem son muy pocos: el abad de San Vicente en 1451 y el escribano Pedro Sánchez de Guadalajara en 1464. No existen más ejemplos de este tipo en el ámbito de las élites.

La celebración de la misa de los nueve días ${ }^{69}$ se consideraba el final de las honras $^{70}$, como reflejan los libros de presencias. Los obituarios desconocen si trascurrían otros ritos entre el sepelio y la eucaristía de novenario, aparte de las citadas misas. Sea como fuere, la celebración de los nueve días no arraigó entre las élites. Apenas se cuentan con cuatro encargos: Pedro Ildefonso en 1451, el matrimonio Sánchez de

\footnotetext{
${ }^{61}$ MARTín CEA, J.C., «El modelo testamentario y su reflejo en los diferentes grupos sociales», Edad Media. Revista de Historia, 6 (2003-2004)», p.118.

${ }^{62}$ Palacios Álvarez, J., «Veyendo que natural cosa es que todo omen que en este mundo nasce que a de finar. Morir en la villa de Miranda de Ebro y su entorno en la transición entre la Edad Media y la Edad Moderna», La muerte en el noroeste de Castila a finales de la Edad Media, GONZÁLEZ MíNGUEZ, C., y BAZÁN DíAZ, I. (coords.), Universidad del País Vasco, Bilbao, 2014, p.30.

${ }^{63}$ 1472, enero, 15, ADT, Cabildo de Párrocos, Libro de presencias de 1472, f.71 v

${ }^{64}$ MARTín CEA, J.C., «El modelo testamentario...», p.121.

${ }^{65}$ Canto introductorio de la hora litúrgica de vísperas, rezo eclesial que se oficiaba al atardecer.

${ }^{66}$ 1451, mayo, 29, ADT, Cabildo de Párrocos, Libro de presencias de 1451, f.74 r.

${ }^{67}$ MARTÍN CEA, J.C., «El modelo testamentario...», p.121.

${ }^{68}$ BALDO AlCOZ, J, «La tradición cristiana del culto...», p.159.

${ }^{69} \mathrm{Su}$ celebración simbolizaba el descanso del finado, tras la purgación de sus pecados. BALDO ALCOZ, J., «La tradición cristiana del culto...», p.164.

${ }^{70}$ 1488, abril, 29, ADT, Cabildo de Párrocos, Libro de presencias de 1488, f.145 v.
} 
Guadalajara en 1464 y Alfonso Fernández de Oseguera el mismo año. Entre los miembros de la nobleza, no se registra ninguna solicitud semejante.

Una vez se cumplía un año del fallecimiento del otorgante, comenzaban las celebraciones de largo plazo, cuya prolongación dependía de varios factores: el poder adquisitivo de los donantes, la voluntad de los herederos y el compromiso de los clérigos. Las celebraciones de largo plazo son las más numerosas y las mejor detalladas en los obituarios, puesto que se suele indicar el templo donde se oficiaron, la ubicación de la tumba del donante y la aportación que aquél realizó al cabildo:

«Aniversario por el ánima del alguaçil Toribio de Ávila e por Beatris Gonçales su esposa e sus defuntos. Fasese en la dicha yglesia de Santiago el tercer día de Pascua de Cincuentena [Pentecostés], la vigilia e otro día la misa. Dexó la dicha Beatris Gonzçales unas casas que son ala granja en el dicho arraval que tienen Juan del Poso e su mujer por doscientos sesenta e cinco mrs» ${ }^{71}$.

Las conmemoraciones englobaban diversos tipos: el cabo de año, las memorias; las festividades y los responsos. El cabo de año era la primera de las conmemoraciones. Su celebración consistía en dos partes: la vigilia y la misa. La vigilia tenía lugar la tarde antes y obedecía a un oficio de lecturas donde se proclamaba el Evangelio ${ }^{72}$. La eucaristía solía celebrarse el día siguiente, coincidiendo con el aniversario del fallecimiento; aunque en otras ocasiones, el testador escogía una fecha cercana a la fiesta de alguna advocación mariana o santo de su devoción. La ceremonia podía transcurrir en la capilla funeraria del otorgante o en el espacio más próximo a su sepultura. Dicha práctica enfatizaba nuevamente la procedencia social del finado:

«Aniversario en la claustra dela iglesia de Toledo del bachiller Alfonso García, canónigo e de su padre e de su madre e de sus hermanos, que ay son sepultados en la puerta de San Pedro a la puerta de la dicha claustra [...] Fasese el XXIX de março, con invitatorio e vigilia e otro día la misa. A de tener licencia el mayordomo para poner altar ençima de las sepulturas» ${ }^{73}$.

Los otorgantes disponían la presencia de diversos símbolos para acreditar su estatus: las capas pluviales de seda, los cetros y la presencia de diáconos y subdiáconos. La nobleza y el alto clero gustaron de tales signos. Sirvan como ejemplo las mandas del conde de Fuensalida:

«Aniversario por don Pedro López de Ayala, conde de Fuensalida e por la señora doña María su mujer, que Dyos aya. Han de hacerse en el ochavario de santa María de septiembre en la tarde, con capas de seda e cetros. E otro día, misa con diacono e con subdiácono para el glorioso aniversario e para el otro que se fase después de la fiesta de los Reyes» ${ }^{74}$.

\footnotetext{
71 1464, s.m., s.d., ADT, Cabildo de Párrocos, Libro de presencias de 1464, f.27 r.

${ }^{72}$ López Martín, J., Historia de la liturgia, Biblioteca de Autores Cristianos, Madrid, 1996, p.310.

73 1472, marzo, 29, ADT, Cabildo de Párrocos, Libro de presencias de 1472, f.15 r.

74 1488, septiembre, s.d, ADT, Cabildo de Párrocos, Libro de presencias de 1488, f.73 r.
} 
El cuarto elemento eran los clamores. Los libros de presencias sólo hacen eco de un caso. El deán Juan de Morales dispuso que todos sus encargos fueran precedidos por varios toques de campana, procedentes de las 26 parroquias de Toledo:

«E otrosy hordenó el dicho nuestro cabildo con el señor deán, que alos dichos seis aniversarios, que ansy an de faser en cada fiesta. [...] sino que fagan taner a cada sacristán de cada perrochya desta cibdad nueve clamores: tres clamores enla tarde de la señal de nona syla oviere, sino ala una. Otros tres clamores ala noche quando tañer el avemaría en la perrochia del señor San Myguel» ${ }^{75}$.

¿Qué significado poseían todos estos símbolos? La solicitud de las capas pluviales buscaba revestir de solemnidad a la misa. Las capas pluviales no eran una prenda litúrgica; sino más bien, su uso era puramente ornamental. Las peticiones de aquéllas pudieron verse influenciadas por el empleo de las mismas en las grandes celebraciones de la catedral ${ }^{76}$. La presencia de numerosos cetros sobre el altar evocaba la imagen de Cristo como luz del mundo y en la esperanza de la resurrección. Pero también, su utilización - como la presencia del diácono y del subdiácono-equiparaba las exequias con el esplendor propio de las principales fiestas cristianas. El tañido de las campanas poseía varios significados. Uno de ellos era el temor a la soledad. La comunicación del fallecimiento buscaba atraer la solidaridad de la comunidad, mediante su participación en las honras fúnebres y con sus oraciones. Otra función poseía un carácter más supersticioso: la de alejar a los demonios, que perseguían la perdición del fiel. La última connotación insistía en la notoriedad del fallecido, puesto que se trataba de una costumbre menos asentada en las ciudades, que en el ámbito rural ${ }^{77}$.

Las memorias correspondían a los aniversarios u otras misas, celebradas muchos años posteriores al fallecimiento. La inclinación del clero y de la élite del común hacia las memorias responde a dos motivos. El primero era que el alma del difunto podría padecer los sufrimientos del Purgatorio durante siglos, el segundo residía en que la memoria era el método más eficiente en la conservación de su recuerdo. La celebración de una memoria podía hacerse por dos vías. Una era la repetición de un aniversario (o varios) durante la fecha solicitada por el fiel. Algunos exponentes son las mandas del arzobispo Gómez Manrique:

«Aniversario en el coro de la Iglesia Mayor por el ánima del noble arzobispo don Gomes. Fásese en fin del mes de abril [de 1450] con responso a la tarde e a la mañana e otro a Pantaleón, canónigo de la dicha iglesia. Está enterrado en [...] enfrente de la pila nueva» ${ }^{78}$.

\footnotetext{
${ }^{75}$ 1488, s.m. s.d, ADT, Cabildo de Párrocos, Libro de presencias de 1488, f.7 r

${ }^{76}$ BARrio Soto, J.L., Vida, Iglesia y Cultura en ..., p.322.

${ }^{77}$ Rodrigo Estevan, M.L., «Muerte y sociabilidad en Aragón (ss. XIV-XV)», Convivir en la Edad Media, MARTín CEA, J.L. (coord.), Dosoles, Burgos, 2010, p.299.

${ }^{78}$ 1436, agosto, 23, ADT, Cabildo de Párrocos, Libro de presencias de 1436, f.51r.
} 
«Aniversario por el ánima del arçobispo de Toledo don Gomis e por Pantaleón canónigo. Fásese en la iglesia mayor, en el coro, a fin de diziembre [1488] con la conmemoración e responsos, e vigilia e misa. Dexó las casas de nuestro cabildo» ${ }^{79}$.

La segunda vía era la capellanía. Los otorgantes asignaban varias rentas fijas al cabildo a cambio de una serie de misas, distribuidas en una periodicidad diaria, semanal o mensual. Los libros de presencias recogen sólo un caso: la capellanía de Juan de Morales. El clérigo legó varias heredades situadas en localidades próximas y algunas casas diseminadas por la ciudad. A cambio, el cabildo debía celebrar una misa diaria para siempre jamás en el convento toledano de Santa Clara:

«An de desyr he celebrar una capellanía perpetua en cada un dya deste mundo, domingos, fiestas e pascuas, sin dexar dela desir ningund día se diga ala misa resada enl dicho monesterio de Santa Clara, enl altar de la dicha capilla del dicho señor don Juan de Morales, deán de Sevilla, la qual dicha misa continya e capellanya se faga por el dicho señor deán, por el ánima de su padre, e de su madre e de sus defuntos» ${ }^{80}$.

Los responsos eran oraciones que encomendaban al difunto a Dios. Si los otorgantes los solicitaban junto a otras conmemoraciones, los clérigos los rezaban tras la finalización del oficio de la tarde ${ }^{81} \mathrm{y}$ de la misa. De igual modo, una práctica común era integrar el responso en otras celebraciones, si su solicitante solo hubiera encargado dicho rezo. Por lo general, los eclesiásticos fueron quienes más los solicitaban, debido a su mayor formación litúrgica; pero más allá de su carácter religioso, el responso se convertía en un elemento más al servicio del esplendor ceremonial, sobre todo si era cantado. Tal y como lo solicitó el chantre Gonzalo Sánchez de Sevilla en 1472:

«Aniversario por Gonzalo Sánchez de Sevilla, capiscol y canónigo de la Iglesia de Toledo e por todos sus difuntos, día de santas Justa y Rufina: vigilia e al otro día misa [...] con sus sendos responsos: uno a la vigilia e otro día la misa, cantados a capella» ${ }^{82}$.

Las festividades fueron quizá el encargo más eclesial; la nobleza las solicitó en menor medida y entre las élites del común no se cuenta con ningún ejemplo. Las fiestas conmemoraban determinadas advocaciones marianas o algunos santos, según las devociones de sus otorgantes. La ausencia de las fiestas cristológicas (apenas 2) contrasta con las dedicadas a María, a los apóstoles (san Andrés, santo Tomé), a los mártires (san Lorenzo, santa Catalina) y a san Miguel, protector del fiel frente al Diablo. Esta tendencia era propia de la piedad del momento, más proclive a recurrir a los intermediarios que a la divinidad, a la que aún se veía un tanto lejana. Como los aniversarios, la celebración de las festividades incluía dos partes. La primera transcurría la tarde anterior, con el rezo de vísperas; la misa se celebraba al día siguiente. A su vez, las fiestas se erigían como memorias. Un ejemplo es la fiesta de San Lorenzo, encargada por el abad de San

\footnotetext{
79 1488, diciembre, 31, ADT, Cabildo de Párrocos, Libro de presencias de 1488, f.117 r.

${ }^{80}$ 1488, s.m, s.d, ADT, Cabildo de Párrocos, Libro de presencias de 1488, f.5 r.

${ }^{81}$ Es decir, la vigilia en caso de que el otorgante solicitara un aniversario y la víspera, si éste pedía la celebración de una festividad como sufragio.

82 1488, julio, 7, ADT, Cabildo de Párrocos, Libro de presencias de 1488, f.52 r.
} 
Vicente, cuya celebración se realizó interrumpidamente desde 1446. Otra característica propia de las solemnidades es la mayor presencia de los elementos paralitúrgicos, respecto a otras celebraciones:

«La fiesta de la Conçepción de Nuestra Señora, en la dicha iglesia [San Nicolás] hordenola el cabildo a suplicación de Guillermo Vasquez regidor e de su mujer la qual dicha fiesta se ha de facer el segundo día de Pascua, día de san Esteban en las tardes vísperas solepmnes con capas y cetros. E otro día de san Juan misa con diácono e con subdiácono e con sermón para la qual dicha fiesta» ${ }^{83}$.

Las fuentes mencionan algunas limosnas ligadas a dos memoriales. Comúnmente, los encargados de su reparto eran los herederos del difunto. Las citadas por las fuentes son las establecidas por los miembros del Cabildo de Curas, mejor posicionados: el canónigo Alfonso García y Juan de Morales. Ambos clérigos habían pertenecido a la corporación, de ahí que solicitaran a los compañeros el reparto de algunas dádivas. El primero pidió que compensaran con un maravedí a los 15 pobres, que asistieran a sus aniversarios $^{84}$. En cambio, las aportaciones de Juan de Morales estuvieron mejor dotadas. El deán ordenó a sus antiguos compañeros la distribución de alimentos y la celebración de la función del Corpus en las prisiones de Toledo, durante la octava de la fiesta:

«El nuestro mayordomo que fuere en cada un año que sea avisado de yr a las carçeles de rey e de arçobispo e el miércoles vigilia de Corpus Xristi, por la mañana. E enmbíe ala carçel de rey dos cargas de leña, quatro cargas de agua e en la del arçobispo una carga de leña, dos cargas de agua. E cuenten los presos que en cada una de las dichas carçeles estovieren e compre e faga llevar este mismo día presente pan cosido e vino e vara e carne e guindas [...] Ytem, en este mismo día de Corpus Christi faga el dicho mayordomo desir en cada carçel una misa ressada» ${ }^{85}$.

Más allá de estos ejemplos no se citan más donativos caritativos pues, como se apuntaba anteriormente, tal cometido era obligación de los herederos y no de los clérigos celebrantes. Una vez analizados la tipología de las mandas, solo resta conocer las preferencias de los diferentes estamentos y qué razones operaron en la solicitud de unos ritos frente a otros. En este sentido, un primer aspecto destacado es el desigual reparto de las mandas entre los diferentes estamentos:

Distribución de las mandas entre los estamentos

\begin{tabular}{c|ccc|}
\hline $\begin{array}{c}\text { Tipo de encargo } \\
\text { Sepelio; misas de }\end{array}$ & Alto clero & Nobleza & Élites del común \\
réquiem y otros & & 11 encargos & 13 encargos \\
\hline
\end{tabular}

\footnotetext{
${ }^{83}$ 1488, diciembre, 26, ADT, Cabildo de Párrocos, Libro de presencias de 1488, f.118 r.

84 1472, marzo, 29, ADT, Cabildo de Párrocos, Libro de presencias de 1472, f.15 r

85 1488, s/m., s/d., ADT, Cabildo de Párrocos, Libro de presencias de 1488, f.43 r.
} 


\begin{tabular}{|c|c|c|c|}
\hline rezos & & & \\
\hline Novenario: & 1 encargos & 1 encargos & 4 encargos \\
\hline Aniversario & 22 encargos & 5 encargos & 5 encargos \\
\hline Memoria & 63 encargos & - & 10 encargos \\
\hline Fiesta & 19 encargos & 2 encargos & - \\
\hline $\begin{array}{c}\text { Responsos, invita- } \\
\text { torios y letanías }\end{array}$ & 71 encargos & 1 encargos & - \\
\hline $\begin{array}{c}\text { Capellanía } \\
\text { Total, mandas de } \\
\text { primer ciclo }\end{array}$ & 15 encargos & 12 encargos & 17 encargos \\
\hline $\begin{array}{c}\text { Total, conmemo- } \\
\text { raciones }\end{array}$ & 176 encargos & 8 encargos & 15 encargos \\
\hline $\begin{array}{c}\text { Total, conjunto } \\
\text { de mandas }\end{array}$ & $\begin{array}{c}76,60 \% \\
191 \text { encargos }\end{array}$ & $\begin{array}{c}8,23 \% \\
13,16 \%\end{array}$ \\
\hline
\end{tabular}

Las acusadas diferencias de los encargos aportan dos interesantes lecturas. Una es la relación de los donantes con la corporación. El clero catedralicio prefirió acudir al Cabildo de Curas, por las estrechas relaciones existentes entre ambos colectivos. Esa vinculación se debía a la participación del clero parroquial en las grandes ceremonias de la catedral ${ }^{86}$, como al hecho que algunos canónigos integraran las filas del clero parroquial e incluso del propio cabildo. Al contrario, las oligarquías laicas se inclinaron más por las órdenes mendicantes ${ }^{87}$. Por una parte, dicha preferencia respondía a la fama de rigor y santidad de los religiosos, frente al clero secular; un rigor de vida que hacían más efectivos sus rezos. Por otra, el encargo de las mandas funerarias a varias entidades religiosas facilitaba dotarse del mayor número de sufragios, con los que atraer la misericordia divina y perpetuar la memoria del fiel.

La segunda lectura expone las preferencias de los otorgantes. Las oligarquías laicas se decantaron por los ritos del primer ciclo. Los nobles y burgueses procuraban asegurarse cuanto antes su redención, así como garantizar el cumplimiento de sus disposiciones. En cambio, el clero se inclinó por las conmemoraciones. Posiblemente, el temor al incumplimiento de sus mandas estuviera menos extendido entre los eclesiásticos, que entre los laicos ${ }^{88}$. Otros posibles factores fueron las diversas estrategias utilizadas por clérigos y seglares, para mostrar su poder y construir su memoria. Si los clérigos apostaron más por el esplendor litúrgico de las conmemoraciones, las élites laicas mostraron mayor predilección por las exequias. Aún así su objetivo era el mismo:

\footnotetext{
${ }^{86}$ Rivera ReCiO, J.F., La Iglesia de Toledo..., pág. 142.

${ }^{87}$ Hacia el siglo XV, las principales órdenes mendicantes estaban asentadas en Toledo, tales como los trinitarios, agustinos, carmelitas, franciscanos y dominicos. Muchas de ellas se vieron beneficiadas por las mandas funerarias. SERRANO Rodríguez, E., Toledo y los dominicos en la época medieval. Instituciones, economía y sociedad, Universidad de Castilla- La Mancha, Cuenca, 2014.

${ }^{88}$ GArcía Hererro, M.C., y FAlCón PÉreZ, M.I., «En torno a la muerte a finales de la Edad Media...», p.176.
} 
manifestar la naturaleza inalterable de su estatus privilegiado. Tanto como el orden social al que representaban.

\section{Impacto de las mandas en el desarRollo del Cabildo de CuRAS y Beneficia- DOS DE TOLEDO}

Conforme han sido analizadas las cuestiones relativas a la institución y a su universo funerario, se plantean dos últimos interrogantes: ¿Qué impacto económico tuvieron las donaciones de las élites? ¿Cómo influyó este proceso en el Cabildo de $\mathrm{Cu}$ ras y Beneficiados? Para responder ambas cuestiones, es necesario atender a tres informaciones: la evolución de las finanzas capitulares, la cuantía de la ración percibida por los miembros de la corporación y la composición del cabildo.

A partir de 1450, los libros de presencias incluyeron la gestión económica de la corporación. Los ingresos del cabildo procedían de la explotación económica de los inmuebles y bienes raíces donados, y de las aportaciones en metálico. En términos generales, la situación económica del cabildo evolucionó positivamente ${ }^{89}$. Las causas fueron la progresiva incorporación de nuevos otorgantes y por consiguiente el aumento de las donaciones. La mayor parte de éstas se realizaban en forma de viviendas; mientras las cesiones de explotaciones agrarias ocuparon un papel secundario ${ }^{90}$. Por el contrario, las dotaciones monetarias se incrementaron lentamente, hasta desplazar a las casas, como la principal fuente de ingresos. En todo este proceso, las élites jugaron un papel destacado, aunque sus aportaciones variaban en función de diversas circunstancias, tales como la propia bolsa del donante, el grado de proximidad de aquél con el cabildo o el tipo de encargo requerido: las conmemoraciones solían estar mejor gratificadas respecto a las exequias.

Evolución de los ingresos (1450-1488) $)^{91}$

\begin{tabular}{|c|c|c|c|c|c|}
\hline Año & Ingresos & Clero & Nobleza & $\begin{array}{l}\text { Elite del co- } \\
\text { mún }\end{array}$ & Total \\
\hline 1450 & $5.520 \mathrm{mrs}$ & $\begin{array}{c}84,84 \% \\
1.120 \mathrm{mrs}\end{array}$ & - & $\begin{array}{l}15,15 \% \\
200 \mathrm{mrs}\end{array}$ & $\begin{array}{c}23,91 \% \\
1.320 \mathrm{mrs}\end{array}$ \\
\hline 1451 & $9.017,5 \mathrm{mrs}$ & $89,01 \%$ & - & $10,98 \%$ & $20,18 \%$ \\
\hline
\end{tabular}

\footnotetext{
${ }^{89}$ Salvo en dos años no consecutivos. El primero fue 1455 en el que el descenso de los encargos con respecto a 1451, produce una reducción de los ingresos. El segundo corresponde a 1472, donde las aportaciones en metálico y otros ingresos adicionales disminuyen, como se advertirá en el texto más adelante.

${ }^{90}$ El cabildo podía explotar las tierras mediante dos fórmulas: el censo enfitéutico o el alquiler, como sucedía con las viviendas.

${ }^{91}$ Ante la confusión que puede suscitar los datos relativos a los ingresos contenidos en el artículo «El Cabildo de Curas y Beneficiados de Toledo. Composición y aspectos institucionales (1455-1488)» y los de esta publicación, cabe aclarar que los recogidos aquí son las cifras definitivas.
} 


\begin{tabular}{|c|c|c|c|c|c|}
\hline & & $1.620 \mathrm{mrs}$ & & $200 \mathrm{mrs}$ & $1.820 \mathrm{mrs}$ \\
\hline $\mathbf{1 4 5 5}$ & $8.160 \mathrm{mrs}$ & $65,15 \%$ & $27,87 \%$ & $6,96 \%$ & $35,17 \%$ \\
& & $1.870 \mathrm{mrs}$ & $800 \mathrm{mrs}$ & $200 \mathrm{mrs}$ & $2.870 \mathrm{mrs}$ \\
\hline $\mathbf{1 4 6 4}$ & $17.219 \mathrm{mrs}$ & $43,45 \%$ & $22,42 \%$ & $34,11 \%$ & $31,07 \%$ \\
& & $2.325 \mathrm{mrs}$ & $1.200 \mathrm{mrs}$ & $1.825 \mathrm{mrs}$ & $5.350 \mathrm{mrs}$ \\
\hline $\mathbf{1 4 7 2}$ & $13.614 \mathrm{mrs}$ & $90,48 \%$ & - & $9,51 \%$ & $33,20 \%$ \\
& & $4.090 \mathrm{mrs}$ & & $430 \mathrm{mrs}$ & $4.520 \mathrm{mrs}$ \\
\hline $\mathbf{1 4 8 8}$ & $9067 \mathrm{mrs}$ & $84,72 \%$ & $9,09 \%$ & $9,88 \%$ & $59,98 \%$ \\
& & $43.775 \mathrm{mrs}$ & $4.915 \mathrm{mrs}$ & $5.120 \mathrm{mrs}$ & $54.030 \mathrm{mrs}$ \\
\hline
\end{tabular}

La evolución económica del cabildo se divide en tres fases. La primera etapa transcurrió entre 1450 y 1460 . Durante este período, la mayor parte de las donaciones procedía del clero. Otro hecho significativo fue que la preeminencia de las viviendas sobre el resto de las donaciones. En muchas ocasiones, el propio otorgante cedía su casa a través de un censo enfitéutico. El dominio de la propiedad se dividía en dos: el dominio real, quedaba en manos del cabildo y el eminente en las del otorgante o sus herederos, quienes podían disfrutar del inmueble. Pero, los enfiteutas debían cumplir una serie de obligaciones, contraídas con el cabildo. Entre éstas se incluía el pago del censo o tributo, el mantenimiento del inmueble y el deber de informar a la corporación, en el caso de venta. Si el cabildo rehusaba comprarla, los enfiteutas procedían a la transacción, si bien el cabildo conservaba el dominio real. En otros casos, los propietarios legaban su residencia directamente, siendo puesta en régimen de alquiler por la corporación. Aunque las rentas procedentes de las viviendas siguieron siendo importantes, conforme la década avanza, las aportaciones en metálico se incrementaron. En lo referido al aumento de los ingresos, la acumulación de nuevos bienes fue clave, mientras el incremento de algunos cánones fue más reducido.

Si el decenio de 1450 se caracterizó por las oscilaciones, en lo que a ingresos se refiere, la incorporación de nuevos donantes durante el segundo período (1460 y 1470) trajo consigo un resultado ambivalente. Hacia el año 1464, las oligarquías contribuyeron cerca el 31,25\% de las ganancias, porcentaje del que un 47,66\% suponían nuevos ingresos. Igualmente, la nómina de donantes se diversificó. Diez años más tarde, la mayor parte de las aportaciones seguían realizándose en forma de viviendas. Pero, las donaciones monetarias cobraron más protagonismo. Además, los donativos de los poderosos ascendieron hasta el 32,20\%, en 1472. De hecho, el 42\% de las legaciones de los potentados habían sido abonadas en ese año, aunque conviene recalcar que las arcas capitulares vieron disminuidos sus ingresos, por la menor cuantía de las aportaciones con respecto a $1464^{92}$. Por último, la tercera fase comenzó en 1488. Este año fue el de mayor recaudación, con un 59,98\%. El número de donantes y sus aportaciones aumentaron considerablemente, al punto que algunas de las partidas mejor dotadas se abonaron en dicho año. Al tiempo que los ingresos se incrementaban, la remuneración de los oficiantes evolucionó al alza. La ración pasó de 3,03 maravedíes en 1450 a 8,25 en 1464 .

\footnotetext{
92 También se debe a la ausencia de otros ingresos adicionales, como traspasos de propiedades entre otros.
} 
Mientras que, en 1488, un clérigo podía percibir 11,36 maravedíes de media. Las raciones no incluían otras gratificaciones extra, como la presencia de los integrantes en la toma de posesión de las nuevas propiedades o el ejercicio de algunas tareas concretas dentro del cabildo. De ahí, el posible atractivo que pudo suponer para el clero parroquial, el hecho de integrarse en la corporación.

Ante estos cambios, ¿Cómo evolucionó la composición clerical del cabildo? ${ }^{93} \mathrm{Se}$ observan tres etapas. La primera fase se extendió entre 1430 y 1450. Aquí se apreció un paulatino aumento de los integrantes (33 en 1436 y 40 en 1455). Durante la segunda fase (h.1460-1470), el cabildo acogió al mayor número de clérigos: 55 en 1464 y 65 en 1472.Tras la recuperación económica del cabildo, la última etapa se inició después de 1472. El número de integrantes se redujo drásticamente a 34 miembros, coincidiendo con el período de mayor actividad funeraria y el de mayor percepción de donaciones. Asimismo, esta etapa se singularizó por el incremento considerable de las mandas procedentes de los estamentos privilegiados y acomodados de la ciudad.

La consolidación de un nutrido patrimonio y la mejor dotación de las raciones favorecieron nuevas afiliaciones hasta llegar a 1488, el mejor año de los abordados para el cabildo. Para este año, la cuota de ingreso al cabildo había pasado de los 150 a los 400 maravedíes. Además, la reducción drástica de los integrantes coincidió con una mayor captación de recursos y una mayor presencia del clero catedralicio, de los linajes locales y de la élite del común entre los benefactores del cabildo. Por lo tanto - con la interacción de los elementos arriba analizados - parece constatable un proceso de elitización de la institución. Si las élites toledanas acudieron a la corporación para sus propios fines, el Cabildo de Curas y Beneficiados de Toledo halló por medio de sus mandas un importante activo económico y de prestigio social. El resultado fue el endurecimiento de los mecanismos de ingreso ¿Las causas? Son dos. La primera sería conservar la buena salud de las arcas capitulares, porque el principal gasto del cabildo era el pago de las raciones. La segunda obedecería a razones de prestigio: si la institución mantenía una buena relación con los poderosos de la ciudad, las restricciones hacia futuras incorporaciones reforzarían ese carácter privilegiado, del que el cabildo querría dotarse para distinguirse de otras entidades clericales. Más aún en un contexto tan clericalizado como Toledo a fines de la Edad Media.

\section{CONCLUSIONES}

Entre los siglos XIV y XV, el protagonismo del individuo en su medio social cristalizó en la proliferación de oficios religiosos, ofrecidos por la salvación de los difuntos. Este fenómeno alentó la consolidación de diversas corporaciones de clérigos seculares, como el Cabildo de Curas y Beneficiados de Toledo. Precisamente, su cometido principal fue la celebración de sufragios pro-ánima por los finados de la institución y por sus

\footnotetext{
${ }^{93}$ Los datos relativos al número de clérigos seculares que integraban el cabildo entre 1436 y 1488 son los definitivos.
} 
donantes fallecidos. En el ámbito de las élites, las razones que explican el gran volumen de encargos no sólo responden a la piedad de los poderosos. Las celebraciones litúrgicas expresaban el estatus socioeconómico del fallecido mediante el despliegue del mayor boato ceremonial posible. También, las diversas honras fúnebres consolidaban la memoria social del difunto. En el caso de la aristocracia, se buscaba crear conciencia del linaje entre las generaciones siguientes. Otro objetivo era la conservación del orden social vigente, meta compartida tanto por el alto clero como por la propia aristocracia. Tal deseo explica que los estamentos privilegiados prologasen sus celebraciones funerarias el máximo tiempo posible, más allá del aniversario de su fallecimiento. Por otra parte, los burgueses utilizaron las mandas funerarias en su aspiración de engrosar las filas de la nobleza.

El comportamiento de las élites toledanas responde a la situación desarrollada líneas atrás, como se aprecia en el gran número de rituales funerarios solicitados por las oligarquías. Tales ritos transcurren desde el óbito hasta varias décadas después. Asimismo, la solicitud de diversos elementos paralitúrgicos es una constante en los encargos del alto clero y de la nobleza, puesto que el uso de incienso, de las capas pluviales o el número de cetros contribuían a dar una mayor solemnidad a las honras fúnebres. No obstante, se aprecian notables diferencias entre las mandas de los estamentos acomodados. Si el clero prefirió las conmemoraciones, la nobleza y la burguesía optaron por aquellas ceremonias que trascurrían entre el sepelio y los nueve días, preferentemente los entierros. La principal razón de estas diferencias se debía al reparto de las mandas, que el otorgante hacía entre diversas corporaciones eclesiales. Los otorgantes querían dotarse el mayor número de rezos y misas de ahí que acudieran tanto al cabildo como a las órdenes mendicantes, si bien los laicos mostraban una mayor predilección por los religiosos. Al mismo tiempo, su prestigio social y las posibilidades de su salvación espiritual aumentaban, gracias a las limosnas repartidas entre el nutrido clero oficiante. Estos factores explican por qué el número de encargos y el de los donantes procedentes de la nobleza y de la élite del común son menores comparados con los del alto clero, que solicitó un mayor número de mandas al Cabildo de Curas y Beneficiados, dadas las buenas relaciones que los canónigos mantenían con sus integrantes.

El impacto de las mandas en el cabildo se concretó en la construcción de un considerable patrimonio. La progresiva incorporación de nuevos donantes trajo consigo la adquisición de numerosas casas y tierras y de las aportaciones en metálico, que desplazarían a las viviendas como la principal fuente de recursos del cabildo. Por lo general y excluyendo coyunturas puntuales - los ingresos del cabildo se incrementaron año tras año. Aunque la explotación de los inmuebles legados fue importante, las ganancias procedieron de la acumulación de nuevas aportaciones. Con diferencia, el alto clero fue el mayor benefactor del cabildo, seguido de lejos por el patriciado urbano y la nobleza. Tal diferencia no sólo se debía al mayor número de encargos que los eclesiásticos hicieron a la corporación, sino también a la tipología de sus mandas. Los prelados y los canónigos 
se inclinaron más por las conmemoraciones, cuyas donaciones anejas estaban mucho mejor dotadas económicamente que las celebraciones posmortem.

El progresivo enriquecimiento de la institución atrajo a numerosos clérigos, que deseaban mejorar sus recursos en un contexto de sobrepoblación eclesial, como era Toledo durante la segunda mitad del siglo XV. Las raciones aumentaron conforme lo hacían los caudales y los encargos de las oligarquías. Así, tras un período inicial (h.1430-1450), presidido por un crecimiento moderado, las afiliaciones aumentaron considerablemente entre 1460 y 1470, pero se frenó en 1488. Los motivos que operaron en este proceso fueron el notable incremento de las rentas de este año, como de los encargos de las élites. Aunque conviene recordar que el Cabildo de Curas y Beneficiados no fue el único instituto eclesiástico que ofició las mandas de las élites toledanas, ni el preferido por los poderosos, lo cierto es que el progresivo incremento de las mandas procedentes de canónigos, nobles u otros personajes acomodados dio lugar al cierre de la institución de cara a nuevas incorporaciones. En clave de síntesis, si las oligarquías civiles y religiosas de la ciudad se sirvieron de las honras fúnebres para plasmar su estatus y consolidar su memoria; el Cabildo de Curas y Beneficiados de Toledo obtuvo importantes recursos económicos y una proyección social relativamente importante, gracias a las mandas funerarias de las élites, en un período en el que el cristianismo y sus expresiones sociales lo impregnaban todo: desde el ámbito cotidiano a los resortes del poder. 